
\title{
28 Research Square \\ Marketing Analysis: Antiemetic Drugs on the Pharmaceutical Market of Uzbekistan
}

\section{Samedinova Dilnoza Nuriddin qizi ( $\nabla$ lady_d_1206@mail.ru )}

PhD student, Department of Industrial Technology of Medicines, Tashkent Pharmaceutical Institute, Tashkent, Uzbekistan https://orcid.org/0000-0002-1706-7055

\section{Yunusova Kholida Mannanovna}

Professor, Department of Industrial Technology of Medicines, Tashkent Pharmaceutical Institute, Tashkent, Uzbekistan

\section{Research Article}

Keywords: antiemetic drugs, nausea, vomiting, DRUG AUDIT, import, dosage forms

Posted Date: October 26th, 2021

DOI: https://doi.org/10.21203/rs.3.rs-1010766/v1

License: (1) This work is licensed under a Creative Commons Attribution 4.0 International License. Read Full License 


\section{Abstract}

In this study, we analysed, with the help of the "State Register of Medicines, Medical Devices and Medical Equipment Permitted for Use in Medical Practice of the Republic of Uzbekistan", the number, dosage forms and cost of registered antiemetic drugs in 2016-2020 based on the DRUG AUDIT program, which offers a database of information from 2016 to 2020.

\section{Introduction}

According to Article 4 of Law No. LRU-399 of the Republic of Uzbekistan, dated January 4, 2016, "On Medicines and Pharmaceutical Activities", the state guarantees the availability of essential medicines as well as medical devices and their quality, includes antiemetic drugs in the list of essential medicines in the Republic of Uzbekistan and notes that their production and availability at accessible prices are especially important for the country's population $[4,12,13]$.

In accordance with Decree No. -5229 of the President of the Republic of Uzbekistan, dated November 7, 2017, "On Measures to Radically Improve the Pharmaceutical Industry Management System", to improve conditions for the development of pharmaceutical activities, increase the provision of affordable, highquality medicines, medical products and medical equipment for the population and health care institutions, and introduce a unified coordination system for the production, import and sale of these items, a market analysis was carried out $[11,14]$.

Antiemetic drugs can treat conditions such as nausea and vomiting that commonly occur with other drugs, such as drugs given for anaesthesia during surgery or chemotherapy for cancer. They can also be used independently to treat vomiting caused by several medical conditions, including chemotherapy, motion sickness, gastroenteritis, general anaesthetics, opioid analgesics, dizziness, pregnancy, food poisoning, emotional stress, and others. Chemotherapy is leading segment of use, as the number of cancer patients is increasing daily. In the case of pregnant women, these drugs bring significant relief to women suffering from morning sickness or nausea in early pregnancy. For some women, morning sickness lasts much longer, and antiemetic drugs are extremely helpful in these situations. Antiemetic drugs are usually taken by the mouth and sometimes by injection $[1,2,8,9,15-18]$.

Demand for antiemetic drugs is mainly fuelled by the rapidly growing geriatric population around the world, which is highly susceptible to diseases such as cancer that are mostly treated with chemotherapy, leading to side effects such as vomiting. In addition, the growing number of patients with gastroenteritis also contributes to the increase in demand $[1,2,6-9,19,20]$.

The market for antiemetics, which has shown strong growth thus far, is likely to expand further, albeit at a slow pace, in the coming years due to the drying up of clinical supplies. The cost of research and development is high, which holds back the development of new drugs. As a result, many experienced companies are carefully considering the possibility of new research projects in the field of molecules or drugs $[1,6,7]$. 
Purpose of the study. To further improve the provision of the population with high-quality, effective and safe pharmaceutical products, expand production volumes, increase the scientific, technical and export potential of domestic manufacturers, and attract foreign direct investment, a five-year analysis was carried out to accompany further plans to improve the identified situation [3].

This article analyses the number of packages and costs associated with the production of domestic products and the supply of antiemetic drugs from CIS and foreign countries to the pharmaceutical market of the Republic of Uzbekistan.

\section{Materials And Methods}

To carry out this analysis, we used the data provided in the "State Register of Medicines, Medical Devices and Medical Equipment Permitted for Use in Medical Practice of the Republic of Uzbekistan" for 20162020 [3], the "List of Essential Medicines" of the Republic of Uzbekistan, approved by Order No. 41 of the Ministry of Health, dated July 20,2018, and registered by the Ministry of Justice of the Republic of Uzbekistan on July 27, 2018, with Registration No. 3045 [5], and information from the DRUG AUDIT program from 2016 to 2020 . We analysed dosage forms, numbers of imports, and costs of produced and imported antiemetic drugs in the Republic of Uzbekistan for 2016-2020.

\section{Results And Discussions}

Based on the "State Register of Medicines, Medical Devices and Medical Equipment Permitted for Use in Medical Practice of the Republic of Uzbekistan" for 2016-2020 and the "DRUG AUDIT" program from 2016-2020, the numbers of domestically produced packages of antiemetic drugs in all dosage forms of antiemetic drugs of domestic production were counted, as were the numbers manufacturers of in the CIS countries and foreign manufacturers countries.

As can be seen from the data in Table 1, the share number of antiemetic drugs produced in the $\mathrm{CIS}$ countries accounteds for from 73,851 to 259,458 the number of imports at its peak in 2017 but, which by 2020 had decreased to 73,851 , the. The share of Fforeign manufacturesmanufacturers of antiemetic drugs accounted for from 92,841 to 266,363 imports, which peaking in 2018 at was almost more than 2 times moretwice the number in each of the two previous years. The share number from of domestic producers, in contrast to the numbers the from CIS and foreign suppliers, was significantly increased from 144,372 to 876,989 (2017) (Fig. 1). 
Table 1

Information on the total number of antiemetic drugs registered in the Republic of Uzbekistan for 20162020

\begin{tabular}{|llllll|}
\hline No & $\begin{array}{l}\text { Manufacturer } \\
\text { / year }\end{array}$ & $\begin{array}{l}\text { Domestic } \\
\text { medicines }\end{array}$ & $\begin{array}{l}\text { Medicines produced in } \\
\text { ClS countries }\end{array}$ & $\begin{array}{l}\text { Foreign } \\
\text { medicines }\end{array}$ & $\begin{array}{l}\text { Total number of } \\
\text { packages, pcs }\end{array}$ \\
\hline 1 & 2016 & 144,372 & 163,450 & 94,388 & 402,210 \\
\hline 2 & 2017 & 876,989 & 259,458 & 92,841 & $1,229,288$ \\
\hline 3 & 2018 & 758,141 & 180,910 & 266,363 & $1,205,414$ \\
\hline 4 & 2019 & 461,670 & 139,350 & 105,325 & 706,345 \\
\hline 5 & 2020 & 361,548 & 73,851 & 163,886 & 599,285 \\
\hline
\end{tabular}

During the study period, the volume of imports of antiemetic drugs from the CIS countries increased by 3.5 times, that from foreign countries by 2.9 times, and that from domestic manufacturers by 6 times.

The results show that antiemetic drugs in all dosage forms and registered and produced by domestic manufacturers for the five years account for an average of $62 \%$ of the total, with the remaining $38 \%$ ( $20 \%$ of the production of CIS countries and $18 \%$ of foreign countries) imported into the country for consumption for foreign currency accounts (Fig. 2).

Table 2 shows the numbers of antiemetic drugs in the form of tablets registered in the Republic of Uzbekistan for 2016-2020. Among the total imports of antiemetic drugs, the production of CIS countries began at 76211 and peaked at 202358 imports but by 2020 had decreased to 73851 . The number from foreign manufacturers of antiemetic drugs ranges from 3300 to 35316 imports, with no imports in 2016. The number of domestically produced antiemetic drugs ranges from 24500 to 67689 , but this drug was not domestically produced in the form of tablets over the last 3 years.

Table 2

Information on the number of antiemetic drugs in the form of tablets registered in the Republic of Uzbekistan for 2016-2020

\begin{tabular}{|llllll|}
\hline № & $\begin{array}{l}\text { Manufacturer } \\
\text { / year }\end{array}$ & $\begin{array}{l}\text { Domestic } \\
\text { medicines }\end{array}$ & $\begin{array}{l}\text { Medicines produced in } \\
\text { ClS countries }\end{array}$ & $\begin{array}{l}\text { Foreign } \\
\text { medicines }\end{array}$ & $\begin{array}{l}\text { Total number of } \\
\text { packages, pcs }\end{array}$ \\
\hline 1 & 2016 & 24,500 & 76,211 & 0 & 100,711 \\
\hline 2 & 2017 & 67,689 & 202,358 & 3,300 & 273,347 \\
\hline 3 & 2018 & 0 & 179,830 & 24,710 & 204,540 \\
\hline 4 & 2019 & 0 & 139,350 & 35,316 & 174,666 \\
\hline 5 & 2020 & 0 & 73,851 & 34,380 & 108,231 \\
\hline
\end{tabular}

The numbers of antiemetic drugs in the form of ampoules registered in the Republic of Uzbekistan for 2016-2020 are shown in Table 3. Within this category of antiemetic drugs, there were no imports from CIS 
countries and no production by domestic manufacturers, and foreign produced antiemetic drugs accounted for 12,065 to 25,740 imports, with no imports in 2017 or 2019.

Table 3

Information on the number of antiemetic drugs in the form of ampoules registered in the Republic of Uzbekistan for 2016-2020

\begin{tabular}{|llllll|}
\hline № & $\begin{array}{l}\text { Manufacturer } \\
\text { / year }\end{array}$ & $\begin{array}{l}\text { Domestic } \\
\text { medicines }\end{array}$ & $\begin{array}{l}\text { Medicines produced in } \\
\text { ClS countries }\end{array}$ & $\begin{array}{l}\text { Foreign } \\
\text { medicines }\end{array}$ & $\begin{array}{l}\text { Total number of } \\
\text { packages, pcs }\end{array}$ \\
\hline 1 & 2016 & 0 & 0 & 25,740 & 25,740 \\
\hline 2 & 2017 & 0 & 0 & 0 & 0 \\
\hline 3 & 2018 & 0 & 0 & 18,570 & 18,570 \\
\hline 4 & 2019 & 0 & 0 & 0 & 0 \\
\hline 5 & 2020 & 0 & 0 & 12,065 & 12,065 \\
\hline
\end{tabular}

Regarding the number of antiemetic drugs in the form of solutions registered in the Republic of Uzbekistan for 2016-2020, among the total imports of antiemetic drugs, the production of CIS countries ranged from 1,080 to 87,239 , with no imports in 2019-2020, and the number of foreign produced antiemetic drugs ranged from 68,648 to 223,083 imports. The numbers produced by domestic manufacturers ranged from 119,872 to 809,300 .

Table 4

Information on the number of antiemetic drugs in the form of solutions registered in the Republic of Uzbekistan for 2016-2020

\begin{tabular}{|llllll|}
\hline № & $\begin{array}{l}\text { Manufacturer } \\
\text { / year }\end{array}$ & $\begin{array}{l}\text { Domestic } \\
\text { medicines }\end{array}$ & $\begin{array}{l}\text { Medicines produced in } \\
\text { ClS countries }\end{array}$ & $\begin{array}{l}\text { Foreign } \\
\text { medicines }\end{array}$ & $\begin{array}{l}\text { Total number of } \\
\text { packages, pcs }\end{array}$ \\
\hline 1 & 2016 & 119,872 & 87,239 & 68,648 & 275,759 \\
\hline 2 & 2017 & 809,300 & 57,100 & 212,113 & $1,078,513$ \\
\hline 3 & 2018 & 758,141 & 1,080 & 223,083 & 982,304 \\
\hline 4 & 2019 & 461,670 & 0 & 70,009 & 531,679 \\
\hline 5 & 2020 & 361,548 & 0 & 106,710 & 468,258 \\
\hline
\end{tabular}

Regarding the number of antiemetic drugs in the form of solution ampoules registered in the Republic of Uzbekistan for 2016-2020, information on the total imports of antiemetic drugs and the number produced by CIS countries and domestic manufacturers was not available; for foreign manufacturers, there were no imports from 2016 to 2019, while in 2020, 10,731 drugs were imported (Table 5). 
Table 5

Information on the number of antiemetic drugs in the form of solution ampoules registered in the Republic of Uzbekistan for 2016-2020

\begin{tabular}{|llllll|}
\hline № & $\begin{array}{l}\text { Manufacturer } \\
\text { / year }\end{array}$ & $\begin{array}{l}\text { Domestic } \\
\text { medicines }\end{array}$ & $\begin{array}{l}\text { Medicines produced in } \\
\text { ClS countries }\end{array}$ & $\begin{array}{l}\text { Foreign } \\
\text { medicines }\end{array}$ & $\begin{array}{l}\text { Total number of } \\
\text { packages, pcs }\end{array}$ \\
\hline 1 & 2016 & 0 & 0 & 0 & 0 \\
\hline 2 & 2017 & 0 & 0 & 0 & 0 \\
\hline 3 & 2018 & 0 & 0 & 0 & 0 \\
\hline 4 & 2019 & 0 & 0 & 0 & 0 \\
\hline 5 & 2020 & 0 & 0 & 10,731 & 10,731 \\
\hline & & & & & \\
\hline
\end{tabular}

The aim of this work was to study the domestic production of different dosage forms of antiemetic drugs registered in the Republic of Uzbekistan, depending on their manufacturers [11].

As seen from the data in Table 6, the analysis of domestically produced dosage forms of antiemetic drugs, based on information from the DRUG AUDIT program for 2016-2020, shows that 2,602,720 packages were produced by local manufacturers; of this total, a significant number were produced by Merrimed Farm, Uzbekistan (2,010,770 packages or 77\%), all of them preparations in the form of solutions.

Table 6

The number of domestically produced medicinal products registered in the Republic of Uzbekistan for 2016 - 2020 by country and manufacturing firm

\begin{tabular}{|lllllll|}
\hline № & Company manufacturer & \multicolumn{2}{l}{ Dosage form / quantity, pcs } & \multicolumn{2}{c|}{ Total } \\
\cline { 2 - 5 } & Tablets & Ampoules & Solutions & $\begin{array}{l}\text { Solution } \\
\text { ampoules }\end{array}$ & \\
\hline $1 \quad \begin{array}{l}\text { Merrimed Farm, } \\
\text { Uzbekistan }\end{array}$ & 0 & 0 & $2,040,770$ & 0 & $2,010,770$ \\
\hline $2 \quad$ Radiks, Uzbekistan & 0 & 0 & 469,761 & 0 & 469,761 \\
\hline $3 \quad \begin{array}{l}\text { Gufik-Avitsenna, } \\
\text { Uzbekistan }\end{array}$ & 92,189 & 0 & 0 & 0 & 92,189 \\
$\begin{array}{l}\text { The total number of packages, } \\
\text { pcs }\end{array}$ & 92,189 & 0 & $2,510,531$ & 0 & $2,602,720$ \\
\hline
\end{tabular}

Figure 3 shows the numbers of domestically produced antiemetic drugs produced in various dosage forms. As seen from Figure 3, a total of 2,602,720 packages were produced, of which 92,189 packages 
were in the form of tablets, $2,510,531$ in the form of solutions, and none in the form of ampoules or ampoule solutions.

As seen from the data in Table 7, the analysis of dosage forms of antiemetic drugs produced in CIS countries, according to the DRUG AUDIT program for 2016-2020, shows that 2,602,720 packages were imported from manufacturers in CIS countries; a significant number of this total were produced by Borisovskiy, Belarus $(659,609$ packages or $97 \%)$, in the form of tablets and solutions.

Table 7

The number of medicines produced in CIS countries registered in the Republic of Uzbekistan for 2016 2020 by country and manufacturing firm

\begin{tabular}{|lllllll|}
\hline № & Company manufacturer & \multicolumn{2}{l}{ Dosage form / quantity, pcs } & Total \\
\cline { 3 - 6 } & & Tablets & Ampoules & Solutions & $\begin{array}{l}\text { Solution } \\
\text { ampoules }\end{array}$ & \\
\hline 1 & Yuria-Farm, Ukraine & 0 & 0 & 1,260 & 0 & 1,260 \\
\hline 2 & Darnitsya, Ukraine & 0 & 0 & 15,000 & 15,000 \\
\hline 3 & Borshagovskiy, Ukraine & 0 & 0 & 1,800 & 0 & 1,800 \\
\hline 4 & Borisovskiy, Belarus & 532,250 & 0 & 127,359 & 0 & 659,609 \\
\hline $\begin{array}{l}\text { Total number of packages, } \\
\text { pcs }\end{array}$ & 532,250 & 0 & 145,419 & 0 & 677,669 \\
\hline
\end{tabular}

Figure 4 shows the number of antiemetic drugs produced in CIS countries in various dosage forms. As seen from Figure 4, a total of 677,669 packages were produced, of which 532,250 packages were in the form of tablets and 145,419 in the form of solutions, while drugs in the form of ampoules and solution ampoules were not produced.

Table 8 The number of medicines produced in foreign countries registered in the Republic of Uzbekistan from 2016 to 2020 by country and manufacturing firm 


\begin{tabular}{|c|c|c|c|c|c|c|}
\hline \multirow[t]{2}{*}{ № } & \multirow[t]{2}{*}{ Company manufacturer } & \multicolumn{4}{|c|}{ Dosage form / quantity, pcs } & \multirow[t]{2}{*}{ Total } \\
\hline & & Tablets & Ampoules & Solutions & $\begin{array}{l}\text { Solution } \\
\text { ampoules }\end{array}$ & \\
\hline 1 & Serena Healthcare, India & 83,734 & 0 & 69,600 & 0 & 153,334 \\
\hline 2 & Cadila, India & 13,972 & 0 & 41,659 & 0 & 55,631 \\
\hline 3 & Agio, India & 0 & 56,375 & 0 & 0 & 56,375 \\
\hline 4 & Dr. Reddy's, India & 0 & 0 & 190,008 & 0 & 190,008 \\
\hline 5 & Baxter Pharmaceuticals, India & 0 & 0 & 40,256 & 0 & 40,256 \\
\hline 6 & Zieva Farm, India & 0 & 0 & 25,000 & 0 & 25,000 \\
\hline 7 & Samarth Life Sciences, India & 0 & 0 & 16,000 & 0 & 16,000 \\
\hline 8 & Mefar Ilac Sanayii, Turkey & 0 & 0 & 1,000 & 0 & 1,000 \\
\hline 9 & Karan Healthcare, India & 0 & 0 & 32,314 & 0 & 32,314 \\
\hline 10 & Claris, India & 0 & 0 & 10,448 & 0 & 10,448 \\
\hline 11 & Elda International DMCC, India & 0 & 0 & 2,179 & 0 & 2,179 \\
\hline 12 & Ultra Laboratories, India & 0 & 0 & 31,931 & 0 & 31,931 \\
\hline 13 & LN Pharma, India & 0 & 0 & 19,436 & 0 & 19,436 \\
\hline 14 & Mankind Pharma, India & 0 & 0 & 28,000 & 0 & 28,000 \\
\hline 15 & Hebei Tiancheng Pharm, China & 0 & 0 & 30,480 & 0 & 30,480 \\
\hline 16 & $\begin{array}{l}\text { Zhangjiakou Kaiwei } \\
\text { Pharmaceutical, China }\end{array}$ & 0 & 0 & 19,680 & 0 & 19,680 \\
\hline 17 & Demo, Greece & 0 & 0 & 0 & 10,731 & 10,731 \\
\hline Tot & number of packages, pcs & 97,706 & 56,375 & 557,991 & 10,731 & 722,803 \\
\hline
\end{tabular}

Figure 5 shows the number of antiemetic drugs produced abroad in various dosage forms. A total of 722,803 packages were produced, of which 97,706 packages were in the form of tablets, 56,375 in the form of ampoules, 557,991 in the form of solutions, and 10,731 in the form of solution ampoules.

Regarding the prices of antiemetic drugs produced by domestic manufacturers in 2016-2020, the value for tablets amounted to 93,249 USD and for solutions to 1,478,945 USD, while ampoules and solution ampoules were not produced (Table 9) [2].

Table 9 Prices of domestically produced medicines registered in the Republic of Uzbekistan for 20162020 


\begin{tabular}{|llllll|}
\hline \multirow{2}{*}{ № } & Company manufacturer & \multicolumn{3}{l|}{ Dosage form / price $(\$)$} & \\
\cline { 3 - 6 } & & Tablets & Ampoules & Solutions & Solution ampoules \\
\hline 1 & Merrimed Farm, Uzbekistan & 0 & 0 & $1,124,274$ & 0 \\
\hline 2 & Radiks, Uzbekistan & 0 & 0 & 354,671 & 0 \\
\hline 3 & Gufik-Avitsenna, Uzbekistan & 93,249 & 0 & 0 & 0 \\
\hline Total cost (\$) & 93,249 & 0 & $1,478,945$ & 0 \\
\hline
\end{tabular}

Regarding the prices of manufactured antiemetic drugs in CIS countries imported for 2016-2020, the value of drugs in the form of tablets was 342,704 USD and of solutions 259,977 USD, while ampoules and solution ampoules were not produced (Table 10) [2].

Table 10 Prices of medicines produced in CIS countries registered in the Republic of Uzbekistan for 20162020

\begin{tabular}{|llllll|}
\hline \multirow{2}{*}{$№$} & Company manufacturer & \multicolumn{3}{l|}{ Dosage form / price $(\$)$} & \\
\cline { 3 - 6 } & & Tablets & Ampoules & Solutions & Solution ampoules \\
\hline 1 & Yuria-Farm, Ukraine & 0 & 0 & 6,762 & 0 \\
\hline 2 & Darnitsya, Ukraine & 0 & 0 & 27,900 & \\
\hline 3 & Borshagovskiy, Ukraine & 0 & 0 & 2,970 & 0 \\
\hline 4 & Borisovskiy, Belarus & 342,704 & 0 & 222,345 & 0 \\
\hline Total cost $(\$)$ & 342,704 & 0 & 259,977 & 0 \\
\hline
\end{tabular}

Regarding the prices of antiemetic drugs manufactured in foreign countries for 2016-2020, the value of drugs in the form of tablets amounted to 265,996 USD, of ampoules to 507,187 USD, of solutions to $1,478,945$ USD and of solution ampoules to 52,434 USD (Table 11) [2].

Table 11 Prices of medicines produced in foreign countries registered in the Republic of Uzbekistan for 2016-2020 


\begin{tabular}{|c|c|c|c|c|c|}
\hline \multirow[t]{2}{*}{ № } & \multirow[t]{2}{*}{ Company manufacturer } & \multicolumn{4}{|c|}{ Dosage form / price (\$) } \\
\hline & & Tablets & Ampoules & Solutions & $\begin{array}{l}\text { Solution } \\
\text { ampoules }\end{array}$ \\
\hline 1 & Serena Healthcare, India & 189,438 & 0 & 174,000 & 0 \\
\hline 2 & Cadila, India & 76,558 & 0 & 260,913 & 0 \\
\hline 3 & Agio, India & 0 & 507,187 & 0 & 0 \\
\hline 4 & Dr. Reddy's, India & 0 & 0 & $1,244,180$ & 0 \\
\hline 5 & Baxter Pharmaceuticals, India & 0 & 0 & 328,662 & 0 \\
\hline 6 & Zieva Farm, India & 0 & 0 & 112,500 & 0 \\
\hline 7 & Samarth Life Sciences, India & 0 & 0 & 85,980 & 0 \\
\hline 8 & Mefar Ilac Sanayii, Turkey & 0 & 0 & 21,300 & 0 \\
\hline 9 & Karan Healthcare, India & 0 & 0 & 412,496 & 0 \\
\hline 10 & Claris, India & 0 & 0 & 583,639 & 0 \\
\hline 11 & Elda International DMCC, India & 0 & 0 & 152,530 & 0 \\
\hline 12 & Ultra Laboratories, India & 0 & 0 & 127,972 & 0 \\
\hline 13 & LN Pharma, India & 0 & 0 & 118,124 & 0 \\
\hline 14 & Mankind Pharma, India & 0 & 0 & 151,200 & 0 \\
\hline 15 & Hebei Tiancheng Pharm, China & 0 & 0 & 27,432 & 0 \\
\hline 16 & $\begin{array}{l}\text { Zhangjiakou Kaiwei Pharmaceutical, } \\
\text { China }\end{array}$ & 0 & 0 & 17,712 & 0 \\
\hline 17 & Demo, Greece & 0 & 0 & 0 & 52,434 \\
\hline Tot & $\operatorname{cost}(\$)$ & 265,996 & 507,187 & $3,818,640$ & 52,434 \\
\hline
\end{tabular}

A comparison of the prices for 2016-2020 of medicines produced by domestic manufacturers and manufacturers in $\mathrm{CIS}$ and foreign countries registered in the Republic of Uzbekistan can be seen in Figure 7.

\section{Conclusion}

This analysis of the dosage forms, volume of imports, prices and number of registered antiemetic drugs for the period from 2016 to 2020 shows that antiemetic drugs in dosage forms such as gel, drops, capsules, ointments, suppositories and suspensions have not yet been imported or manufactured by domestic manufacturers. Tablets, ampoules and solution ampoules are smaller and are the primary dosage form registered in the Republic of Uzbekistan. Today, demand for tablet and solution dosage 
forms among the population remains important for our further research and for the choice of which drug forms to import.

Antiemetic drugs are produced in sufficient quantities in the form of solutions, but the price of imported products from foreign countries is quite expensive. This shows that it is necessary to pay great attention to the production of domestic drugs that are not inferior to those produced by foreign manufacturersboth in terms of prices and the availability of dosage forms.

Considering that the share of antiemetic drugs in the form of solutions is significant in comparison to the shares of other dosage forms, we consider it expedient to produce this drug form on the basis of demand from the population of the Republic of Uzbekistan.

\section{Declarations}

\section{Acknowledgements}

The authors have contributed equally to the analysis of antiemetic drugs in the Republic of Uzbekistan.

No competing interests were declared.

\section{References}

1. Antiemetic Drugs Market Analysis: By Type of Drug (5-HT3 receptor antagonists, Dopamine antagonists, Steroid-Corticosteroids, Benzodiazepines, NK1 receptor antagonist, Antihistamines, Cannabinoids, Anticholinergic); By Application With Forecast (2016-2021). BioPortfolio. 2021: 1133.

2. Yunusova Kh.M., Samedinova D.N. Analysis of the volume and cost of import of metoclopramide tablets in the Republic of Uzbekistan. EPRA International Journal of Multidisciplinary Research. 2021.Vol.7: 97-102.

3. State register of medicines and medical devices registered in the Republic of Uzbekistan. 2016-2020.

4. The Law of the Republic of Uzbekistan on Amendments and Additions to the Law of the Republic of Uzbekistan "On Medicines and Pharmaceutical Activity". January 4, 2016. LRU No. -399.

5. Order of the Minister of Health of the Republic of Uzbekistan "On approval of the List of essential medicines". July 20, 2018. No. 41.

6. Samedinova D.N., Yunusova Kh.M. Research in the field of selection of the optimal composition of tablets based on metoclopramide. Materials of the international scientific-practical conference "The current state of the pharmaceutical industry: Problems and prospects". Tashkent. 2020: 84-85.

7. Samedinova D.N., Yunusova Kh.M. Study of the antiemetic activity of metoclopramide tablets. VII AllRussian scientific and practical conference with international participation "Prospects for the 
introduction of innovative technologies in medicine and pharmacy". Scientific and practical journal Orekhovo-Zuevo. 2020. No. 4: 268.

8. Samedinova D.N., Yunusova Kh.M. On the development of technology for an antiemetic drug in the form of tablets. XXXIII Scientific and practical conference with international participation "Medicines for humans. Modern problems of pharmacotherapy and prescribing drugs". National University of Pharmacy. Kharkiv. 2020: 491-493.

9. Samedinova D.N., Yunusova Kh.M. Prospects for their production of antiemetic drugs in the Republic of Uzbekistan. XXXIII Scientific and practical conference with international participation "Medicines for humans. Modern problems of pharmacotherapy and prescribing drugs". National University of Pharmacy. Kharkiv. 2020: 493-495.

10. Usmanov U.Kh., Zainutdinov Kh.S., Komilov Kh.M. Content analysis of the nomenclature of antiulcer drugs registered in the Republic of Uzbekistan. Pharmaceutical journal. 2019. No. 1: 13-21.

11. Decree of the President of the Republic of Uzbekistan "On measures to radically improve the pharmaceutical industry management system”. November 07, 2017. No. PD-5229.

12. Resolution of the Cabinet of Ministers of the Republic of Uzbekistan "On approval of the Regulation on the procedure for state registration of medicines, medical devices and medical equipment and the issuance of a registration certificate". March 23, 2018. No. 213.

13. Order of the Minister of Health of the Republic of Uzbekistan "On approval of the list of essential medicines". March 23, 2021. No. 3289.

14. Decree of the President of the Republic of Uzbekistan "On further measures for the accelerated development of the pharmaceutical industry of the republic in $2019-2021$ " (with amendments and additions as of 12.12.2019). April 10, 2019. No. PD-5707.

15. Berger M. J., Ettinger D. S., Aston J., Barbour S., Bergsbaken J., Bierman P. J., Brandt D., Dolan D. E., Ellis G., Kim E. J., Kirkegaard S., Kloth D. D., Lagman R., Lim D., Loprinzi C., Ma C. X., Maurer V., Michaud L. B., Nabell L. M., Hughes M. (2017). Antiemesis, version 2.2017 featured updates to the NCCN guidelines. JNCCN Journal of the National Comprehensive Cancer Network, 15(7): 883-893. https://doi.org/10.6004/jnccn.2017.0117

16. Roila F., Hesketh P.J., Herrstedt J. Antiemetic Subcommitte of the Multinational Association of Supportive Care in Cancer. Prevention of chemotherapy- and radiotherapy-induced emesis: results of the 2004 Perugia International Antiemetic Consensus Conference. Ann Oncol. 2006 Jan;17(1):20-8. doi: 10.1093/annonc/mdj078. Epub 2005 Nov 28. PMID: 16314401.

17. Feyer P.Ch., Maranzano E., Molassiotis A. et al. Radiotherapy-induced nausea and vomiting (RINV): antiemetic guidelines. Support Care Cancer 2005; 13:12-128.

18. Maranzano E., Feyer P.Ch., Molassiotis A. et al. Evidence-based recommendations for the use of antiemetics in radiotherapy. Radiother Oncol 2005; 76: 227-233.

19. Li S.T., DiGiuseppe D.L., Christakis D.A. Antiemetic use for acute gastroenteritis in children. Arch Pediatr Adolesc Med. 2003;157(5):475-479. 
20. Leung A.K., Robson W.L. Acute gastroenteritis in children: role of antiemetic medication for gastroenteritis-related vomiting. Paediatr Drugs. 2007;9(3):175-184.

\section{Figures}

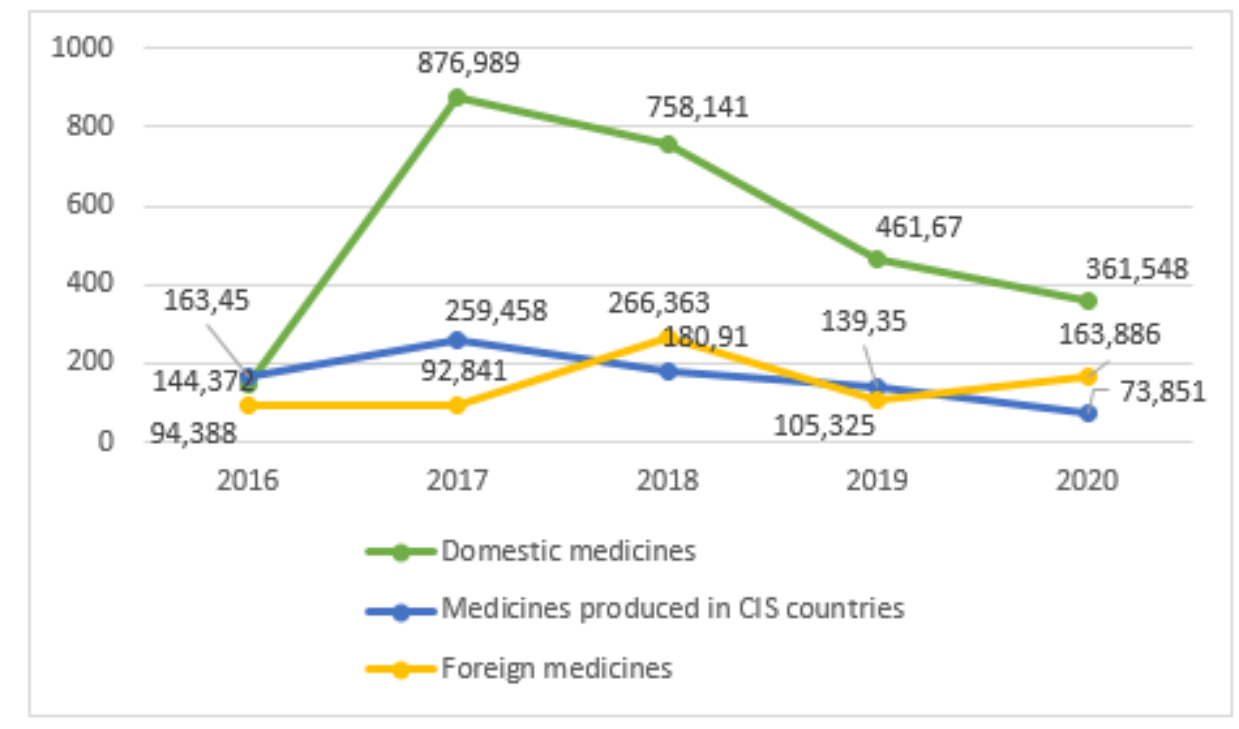

\section{Figure 1}

The volume of imports of all registered dosage forms of antiemetic drugs from domestic, CIS and foreign manufacturers to the Republic of Uzbekistan

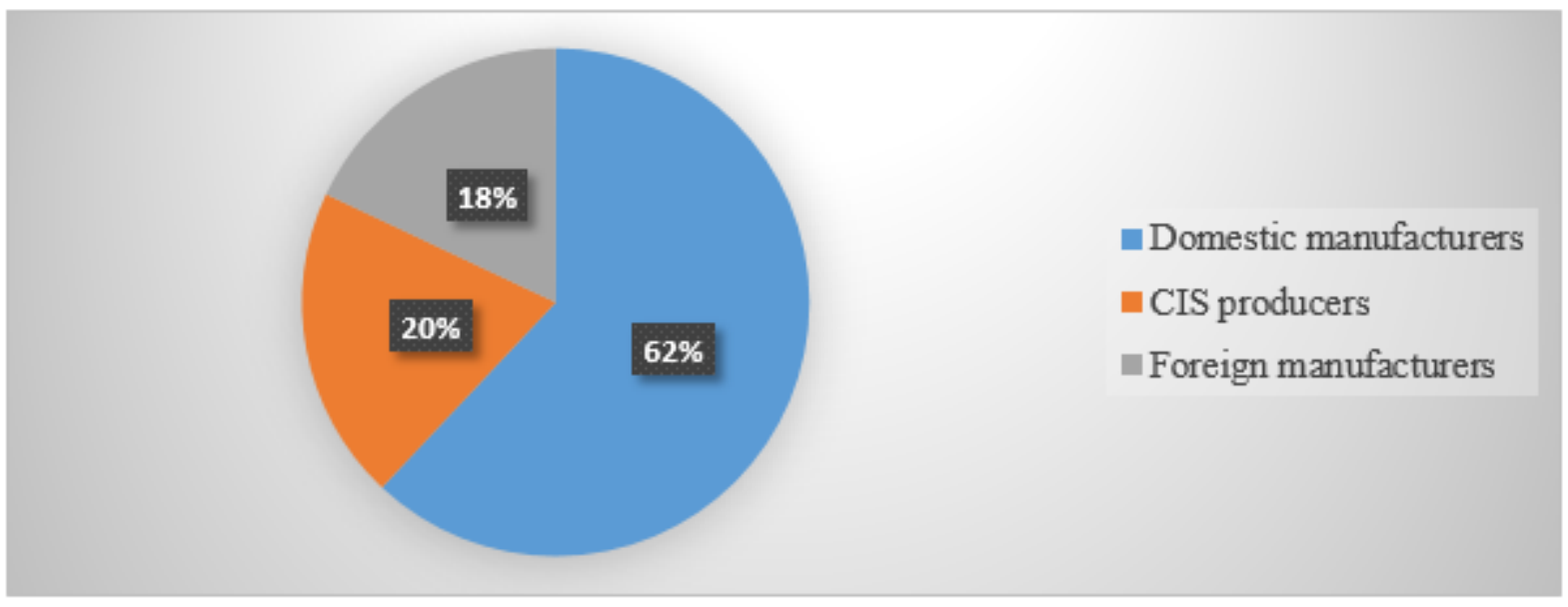

\section{Figure 2}

Shares of all registered dosage forms of antiemetic drugs by country (2016-2020) 


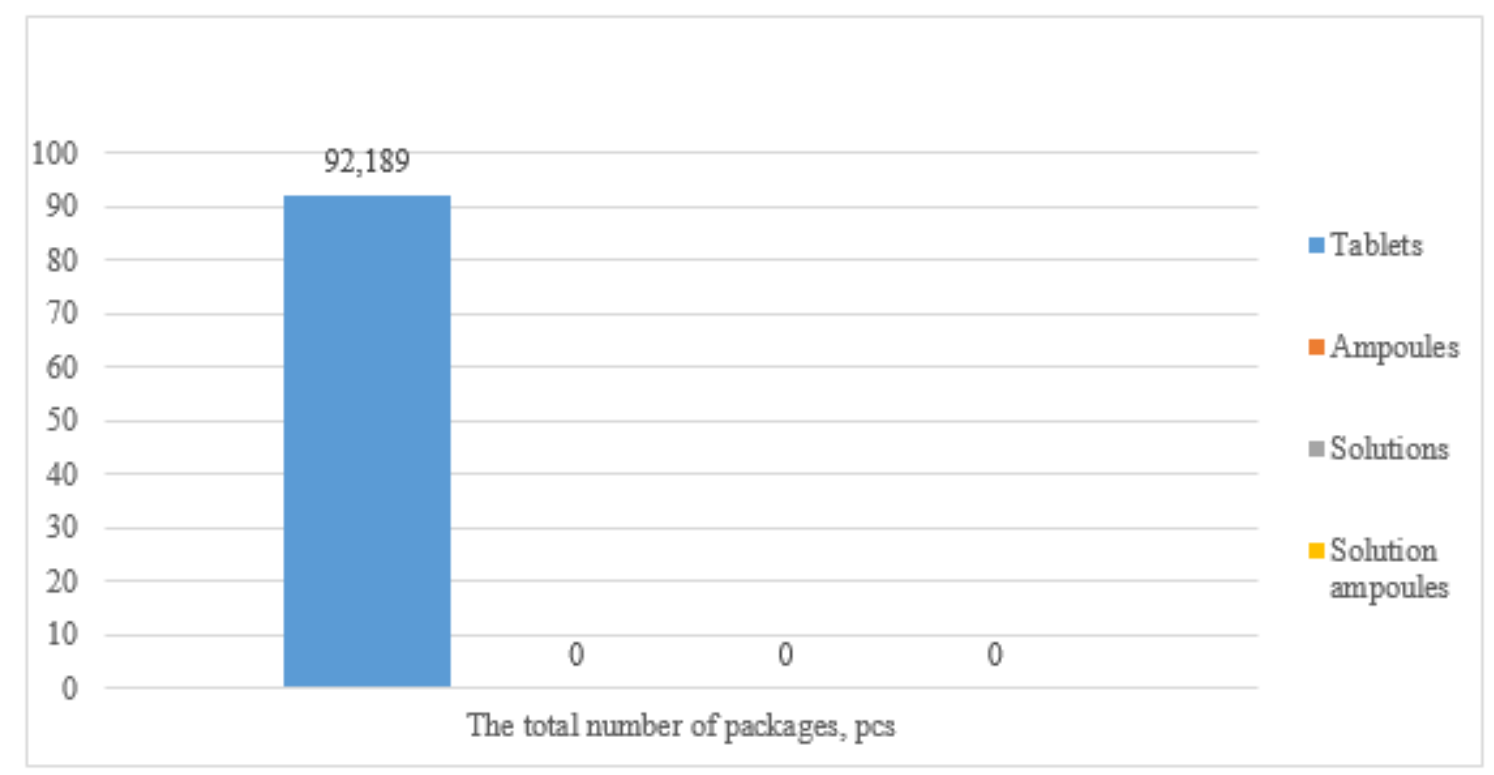

\section{Figure 3}

Domestically produced antiemetic drugs in various dosage forms

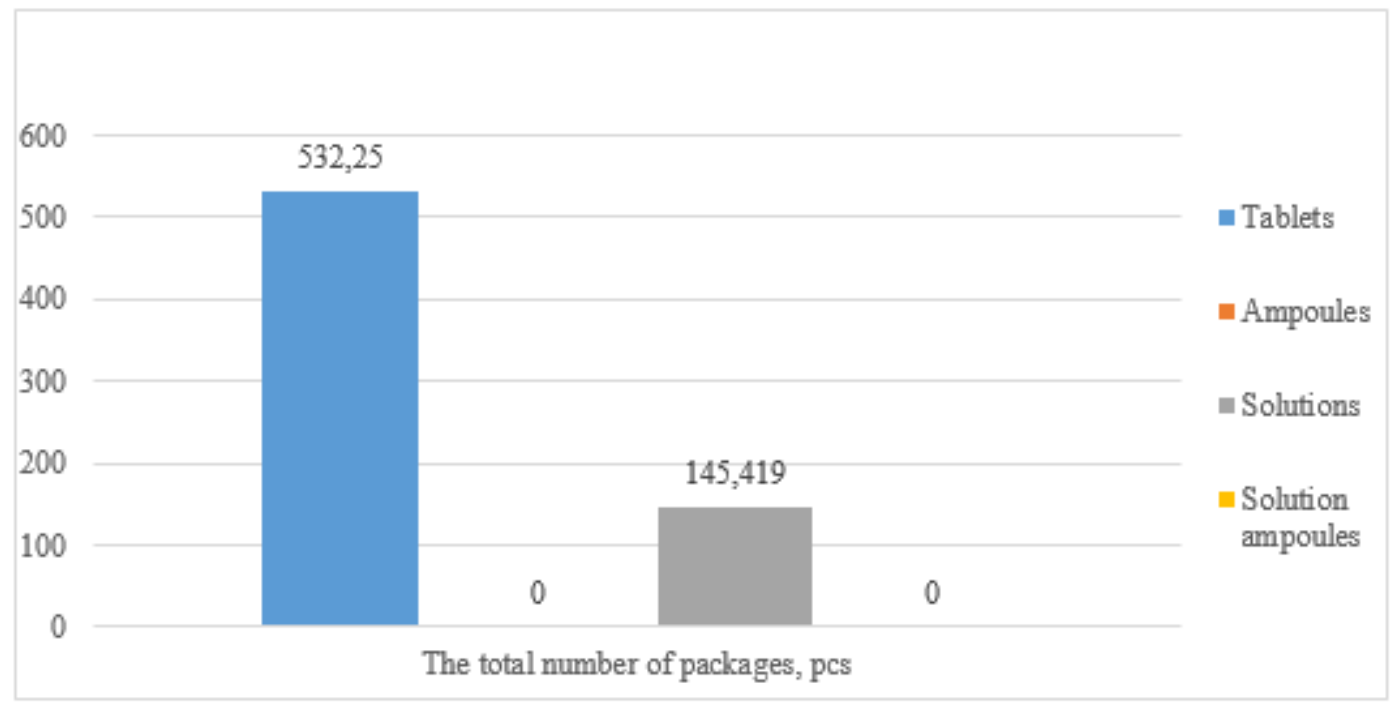

Figure 4

Number of antiemetic drugs produced in CIS countries in various dosage forms 


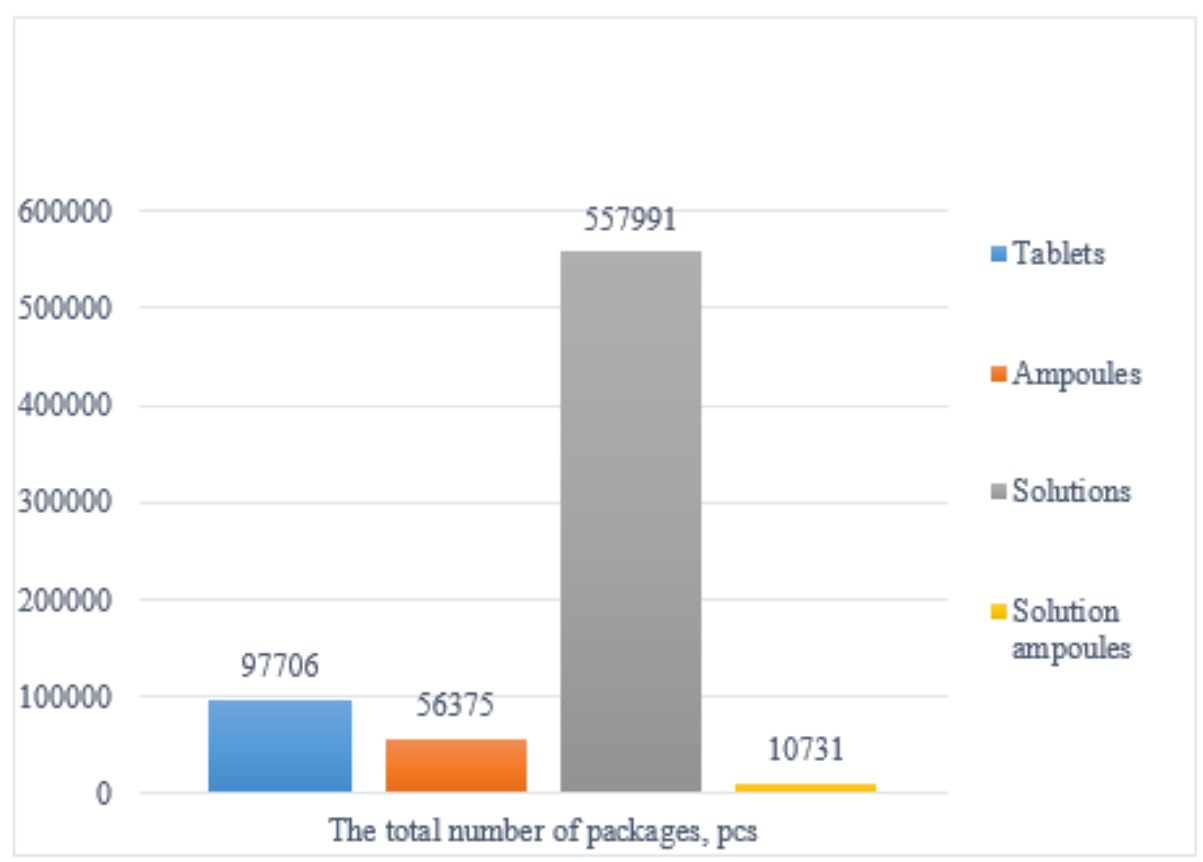

\section{Figure 5}

Number of antiemetic drugs produced in foreign countries, and produced in various dosage forms

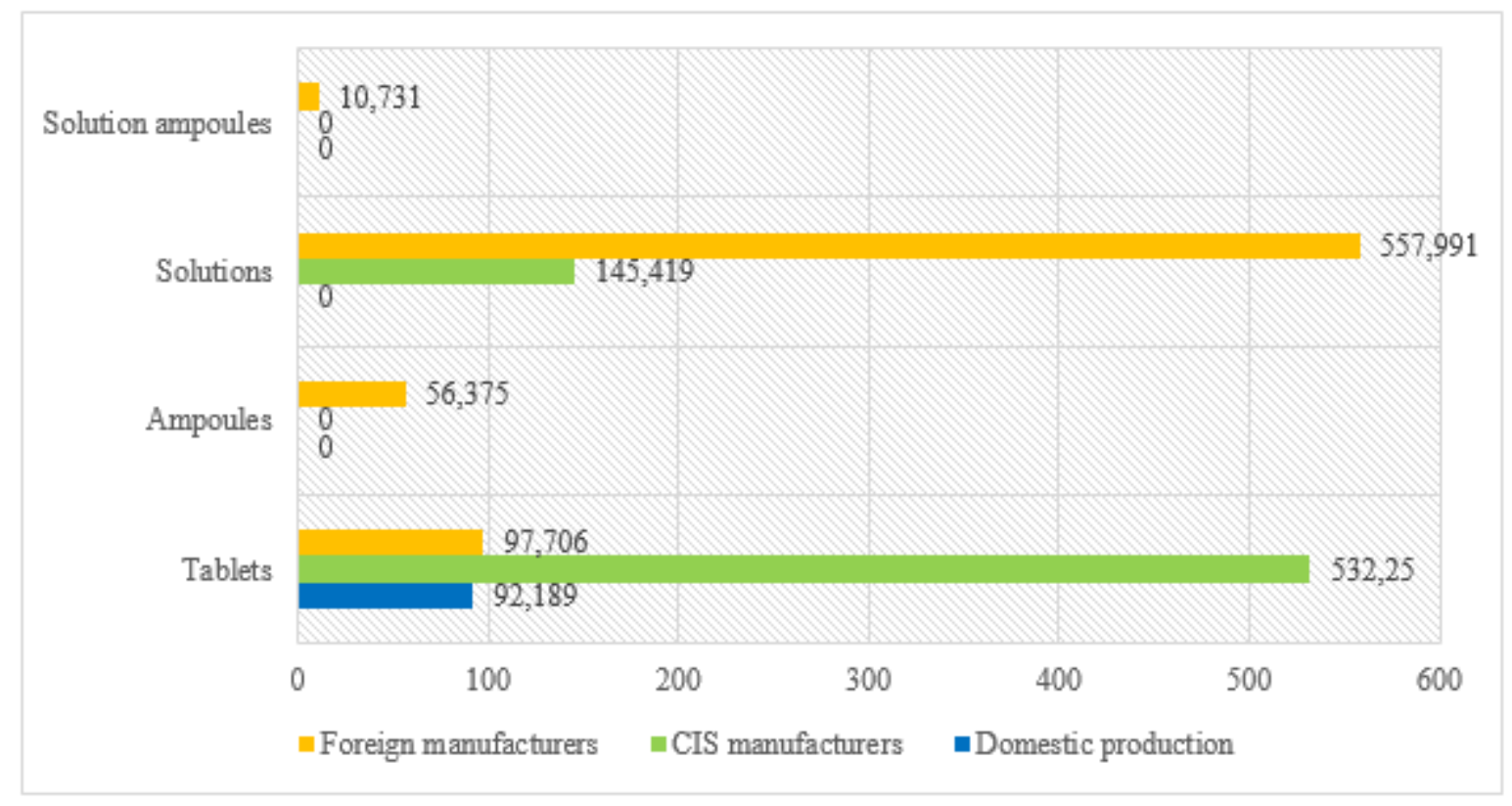

Figure 6

Number of drugs registered in the Republic of Uzbekistan for 2016-2020 and produced domestically, by manufacturers in $\mathrm{ClS}$ countries and foreign manufacturers 


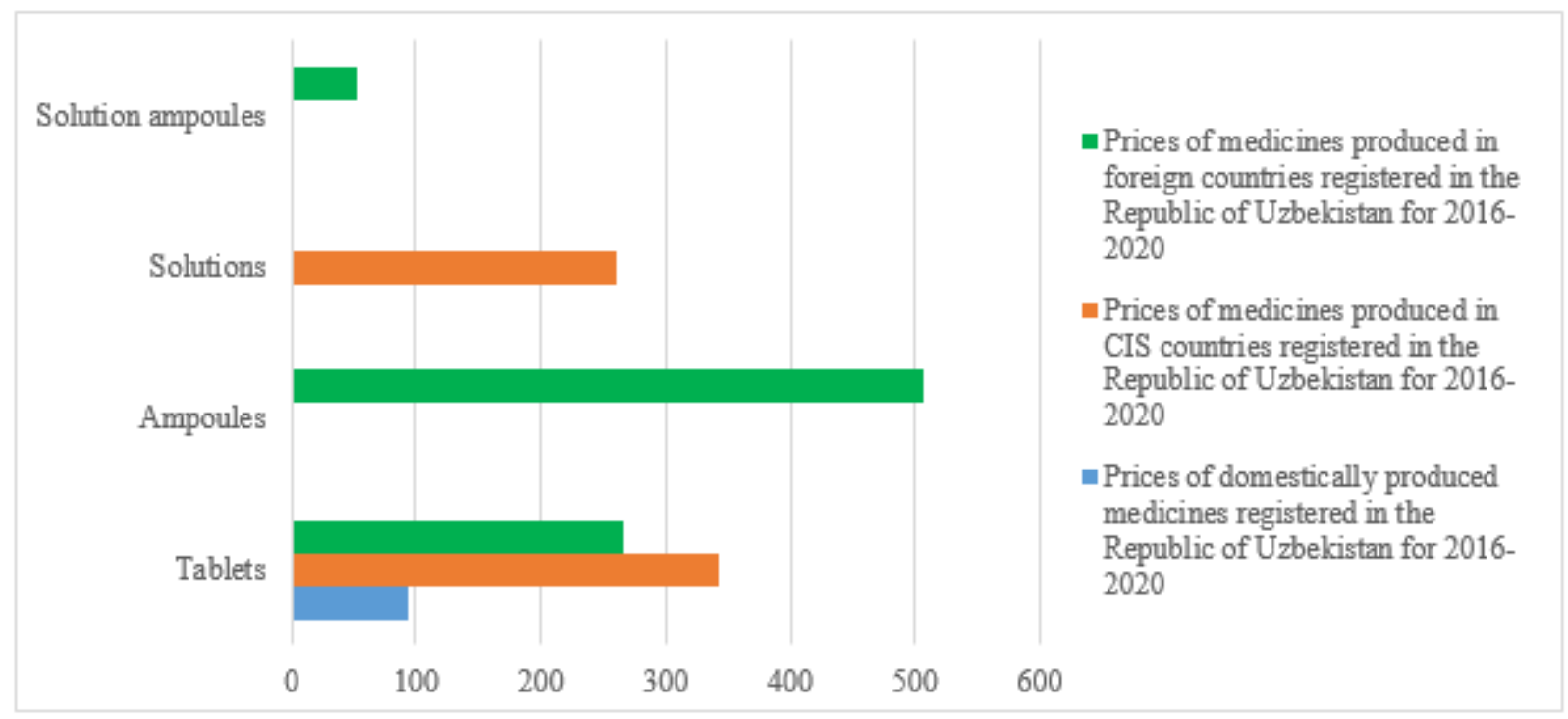

\section{Figure 7}

Cost of medicines registered in the Republic of Uzbekistan (2016-2020) from domestic manufacturers and manufacturers in CIS and foreign countries 